\title{
Lewis-Sumner sindromas, pasireiškęs poūmiu abipusiu peties rezginio pažeidimu
}

\author{
V. Regelskyte் \\ A. Klimašauskienè \\ G. Kaubrys \\ Vilniaus universiteto Medicinos \\ fakulteto Klinikines medicinos \\ instituto Neurologijos \\ ir neurochirurgijos klinika
}

\begin{abstract}
Santrauka. Lewis-Sumner sindromas (L-SS) - tai daugiažidininė ịgyta demielinizuojanti sensorinė ir motorinė neuropatija, asimetrinis lètinès uždegiminès demielinizuojančios polineuropatijos (LUDP) variantas, kai pažeidžiamos viršutinès ir (ar) apatinès galūnès. Sindromo dažniausios klinikinès išraiškos yra asimetrinis ar daugiažidininis jutimų sutrikimas bei jẻgos sumažèjimas ir elektrofiziologiškai nustatomi motorinių nervų laidumo blokai. Straipsnyje aprašomas pacientas, kuriam L-SS pasireiškẻ tik viršutinių galūnių pažeidimu, nei laboratoriniuose, nei elektrofiziologiniuose tyrimuose pakitimu nebuvo rasta. Lewis-Sumner sindromo diagnozė patvirtinta atlikus peties rezginio magnetinio rezonanso tyrimą. L-SS - retas sindromas, jo diagnostika ir gydymas yra sudètingi, nes tyrimai atlikti su nedideliu pacientų skaičiumi ir rezultatai neretai yra prieštaringi.
\end{abstract}

Raktažodžiai: Lewis-Sumner sindromas, daugiažidininė igyta demielinizuojanti sensorinė ir motorinė neuropatija, MADSAM.

\section{IVADAS}

Abipusis peties rezginio pažeidimas - itin retas klinikinis sindromas, kadangi dažniausios peties rezginio pažeidimo priežastys yra susijusios su lokaliu procesu [1]. Susirgimo aplinkybès ir ligos eiga padeda išsiaiškinti dažniausius etiologinius veiksnius - traumos, navikinio proceso ar radiacinio gydymo sukeltą peties rezginio pažeidimą, tačiau galimos ir kitos retesnès priežastys: uždegiminis autoimuninis procesas, išemija, metaboliniai, genetiniai veiksniai $[1,2]$. Siame straipsnyje pristatomas klinikinis atvejis pasireiškè abipusiu peties rezginio pažeidimu, o imuninio uždegimo etiologiją patvirtino magnetinio rezonanso tomografijos (MRT) radiniai, kitos priežasties nebuvimas ir atsakas ị imunomoduliuojantị gydymą.

Imuninès neuropatijos - tai gana retų, bet diagnostiškai svarbių neuropatijų grupè, kadangi galima taikyti efektyvų gydymą [3]. Pagal klinikinę eigą imuninès neu-

\author{
Adresas: \\ Vaiva Regelskyte \\ Vilniaus universiteto ligoninès Santaros klinikos, \\ Neurologijos centras \\ Santariškiu g. 2, LT-08661 Vilnius \\ El.paštas v.regelskyte@gmail.com
}

ropatijos skirstomos i ūmias, iš ju dažniausias Guillain-Barre sindromas, ir lẻtines: lètinę uždegiminę demielinizuojančią neuropatiją (LUDP) ir jos retesnius atipinius variantus, daugiažidininę (multifokalinę) motorinę neuropatiją (angl. multifocal motor neuropathy, MMN) bei kitas retesnes neuropatijas (POEMS sindromą, neuropatijas, susijusias su mielino asocijuotu glikoproteinu (antiMAG neuropatijas)) [4]. Imuninių neuropatijų patogenezè nèra iki galo aiški, manoma, kad jas sukelia imuninių ląstelių ir (ar) antikūnų poveikis periferiniams nervams, nulemiantis jo disfunkciją: nervo mielino pažeidimą (demielinizaciją) ir (ar) aksono pažeidimą (aksonopatiją) [4, 5]. Imuninès neuropatijos skiriasi savo klinikine išraiška, elektrodiagnostinių, laboratorinių tyrimų rezultatais. Reikalingas visų šių duomenų kompleksinis vertinimas, nustatant tikslią diagnozę ir pasirenkant tinkamiausią gydymą $[3,4]$.

Lètinè uždegiminè demielinizuojanti polineuropatija (LUDP) yra imuninė neuropatija, kurios tipinei formai būdingas simetrinis motorinių ir sensorinių visų keturių galūnių nervų skaidulų pažeidimas dèl uždegimo ir jo sąlygojamos demielinizacijos [6, 7]. Yra daug fenotipinių LUDP variantų, todèl manoma, kad LUDP reikètų vadinti ne atskira liga, bet ligų grupe ar sindromu, apimančiu jos visus variantus $[6,8]$. Tipinė LUDP pasireiškia tik $51 \%$ visų atvejų, dažniausias atipinis LUDP variantas yra sensorinè

(C) Neurologijos seminarai, 2018. Open Access. This article is distributed under the terms of the Creative Commons Attribution 4.0 International License CC-BY 4.0 (http://creativecommons.org/licenses/by/4.0/), which permits unrestricted use, distribution, and reproduction in any medium, provided you give appropriate credit to the original author(s) and the source, provide a link to the Creative Commons license, and indicate if changes were made. 
LUDP (iki 35 \% visų LUDP atvejų). Kitų variantų dažnis, skirtingų studijų duomenimis, varijuoja nuo kelių iki keliolikos procentų (2-17 \% visų LUDP atvejų): daugiažidininè igyta demielinizuojanti sensorinè ir motorinè polineuropatija (angl. multifocal acquired demyelinating sensory and motor neuropathy, MADSAM), distalinè igyta demielinizuojanti simetrine (angl. distal acquired demyelinating symmetric neuropathy, DADS) neuropatija, ūmios pradžios LUDP, motorinė LUDP, lètinė imuniné sensorinè poliradikulopatija ir rečiausias LUDP variantas (iki $1 \%$ atvejų) - židininė LUDP [6, 9].

Šame straipsnyje nagrinejjamas atipinis LUDP variantas - MADSAM, ji aprašiusių autorių dar vadinamas Lewis-Sumner sindromu (L-SS). L-SS - tai daugiažidininė igyta demielinizuojanti sensorinė ir motorinė neuropatija, asimetrinis LUDP variantas, kai pažeidžiamos viršutinès ir (ar) apatinės galūnės [7, 10]. L-SS paplitimas nurodomas 1-9 atvejais 1000000 gyventojų ir yra apie dešimt kartų rečiau diagnozuojamas nei LUDP (jos paplitimas 0,8-8,9 atvejo 100000 gyventojų) [6, 14]. Pirmą kartą Lewis-Sumner sindromas buvo aprašytas $1982 \mathrm{~m}$. R. A. Lewis ir kolegų kaip lètinė uždegiminè demielinizuojanti poliradikuloneuropatija [11]. Pirmajame šio sindromo aprašyme minimas išskirtinai tik ranku pažeidimas, rasti daugiažidininiai laidumo blokai elektroneurografijoje, taip pat buvo būdingas geras atsakas į gydymą gliukokortikoidais [11]. Ši publikacija buvo laikoma pirmuoju daugiažidininès motorinès neuropatijos (MMN) aprašymu, tačiau visiems aprašytiems pacientams pasireiškė ir objektyvūs sensoriniai simptomai. S. J. Oh ir bendraautorių $1997 \mathrm{~m}$. publikuotoje studijoje pirmą kartą buvo apibūdinti L-SS (MADSAM) ir MMN skirtumai [12]. Joje pateikiami svarbiausi bruožai, būdingi L-SS ir padedantys atskirti nuo MMN: trumpesnè ligos eiga, sensorinis deficitas ir sensorinių nervų laidumo pokyčiai elektroneurografijoje, daugumai nerandama antikūnų prieš monosialotetraheksozilgangliozidus (GM1) (anti-GM1 antikūnų), geras atsakas ị gydymą gliukokortikoidais. L-SS buvo priskirta LUDP atipiniam variantui ir tapo tarpine grandimi tarp LUDP ir MMN [12, 13].

Pateikiamas atvejo aprašymas, kurio klinikinė išraiška, tyrimų rezultatai ir atsakas ị gydymą, autorių nuomone, turètų būti priskirti Lewis-Sumner sindromui (MADSAM).

\section{KLINIKINIS ATVEJIS}

27 metų vyras, atvykęs ị Vilniaus universiteto ligoninę Santaros klinikas (VUL SK), skundèsi rankų užtirpimu ir silpnumu (rankas šiek tiek galèjo pajudinti per pečius), taip pat prakaitavimu, dažnu širdies plakimu. Minèti simptomai prasidejo prieš mėnesị ir pamažu progresavo: iš pradžių pradejo skaudèti abi rankos dilbių srityje, atsirado rankų tirpimas distaliai nuo alkūnių. Pacientas siejo minètus simptomus su rankų nuovargiu ir skausmu dèl ilgo darbo kompiuteriu. Taip pat pastebèjo, kad kartais stip- riau prakaitavo, bet nekarščiavo. Kelis kartus matavo arterinị kraujospūdị, kuris buvo normalus, tačiau pastebėjo, kad kartais padažnėdavo pulsas. Dèl dažno pulso lankėsi ambulatoriškai poliklinikoje, elektrokardiogramoje fiksuotas širdies susitraukimų dažnis - 176 kartai per minutę. Atlikta širdies echoskopija - be pakitimų. Prieš 2 savaites pastebejo, kad pamažu nusilpo rankos, buvo sunku nulaikyti daiktus. 2017 m. spalio mènesị rankos dar labiau nusilpo: negalèjo vairuoti, atidaryti durų, rengtis. Kojos visą tą laiką išliko stiprios. Kreipèsi ị VUL SK Prièmimo skyrių ir buvo hospitalizuotas ị Nervų ligų skyrių tolimesniam ištyrimui bei gydymui, ịtariant Guillain-Barre sindromą.

Gyvenimo anamnezėje pažymima, kad nenurodẻ neseniai persirgtų infekcijų. Traumų nebuvo. Kitomis lètinèmis ligomis nesirgo. Pernai kelis kartus pasiskiepijo nuo erkinio encefalito. Erkių ịkandimų nepastebejjo. Rūkè po $1-1,5$ pakelio per dieną.

Objektyvios apžiūros metu paciento arterinis spaudimas siekė 110/80 mmHg, pulsas - 70 kartų per minutę. Pacientas nekarščiavo. Buvo sąmoningas, kontaktuojantis, orientuotas laike, vietoje ir savyje. Kalbejjo aiškiai. Galviniai nervai - be pakitimų. Vertinant rankų jègą, abiejų žastų jèga buvo apie 2-3 balus pagal MRC skalę (angl. Medical Research Council), abiejų dilbių jèga - apie 2 balus, plaštakų - 1-2 balai, pirštų - 1 balas (minimalūs judesiai). Raumenų tonusas rankose buvo žemas. Sausgyslių refleksai rankose: dvigalvio žasto raumens ir stipinkaulio antkaulio refleksai neišgauti abipus, trigalvio raumens - labai žemas abipus. Kojų jèga buvo normali - 5 balai pagal MRC skalę, raumenų tonusas - normalus. Refleksai kojose - kiek gyvesni, simetriški, Achilo sausgyslių refleksai neišnykę. Jutimai (skausmo, lietimo, gilieji, temperatūros) galūnèse nesutrikę, jutimų pasikeitimo lygio pacientas nenurodè. Meninginiai simptomai - neigiami. Rombergo pozoje šiek tiek svyravo. Dubens organų funkcijų sutrikimo nebuvo.

Pacientas buvo skubiai tirtas itariant Guillain-Barre sindromą. Atlikti bendrasis kraujo tyrimas ir eritrocitu nusėdimo greitis, gliukozės, elektrolitų, kreatinino, CRB tyrimai - be pakitimų, kreatinkinazès kiekis kraujyje - normalus (109 TV/l). Atlikus juosmeninę punkciją, smegenų skysčio rezultatai atitiko normą: citozè - 1 ląstelè/ $\mu \mathrm{l}$, bendra baltymo koncentracija smegenų skystyje - 0,279 g/1. Atlikta elektroneuromiografija (ENMG) - elektroneurografiškai tirtuose rankų ir kojų nervuose, elektromiografiškai dešinės rankos žasto dvigalviame raumenyje pakitimų nestebèta (neregistruoti spontaninio aktyvumo potencialai, motorinių vienetų veikimo potencialų ištirta nedaug, nes pacientas beveik neịtempé raumens, tačiau registruoti buvo normalūs). Pateikta išvada, kad tokie radiniai prieštarauja ūminès demielinizuojančios polineuropatijos (t. y. Guillain-Barre sindromo) diagnozei, ypač atsižvelgiant ị tai, kad pacientas serga jau 1 mènesị. Atliktas stuburo kaklinės dalies magnetinio rezonanso tomografijos (MRT) tyrimas, jo išvada: nedidelio laipsnio stuburo degeneraciniai pokyčiai, nugaros smegenys - be matomų patologinių pakitimų. 


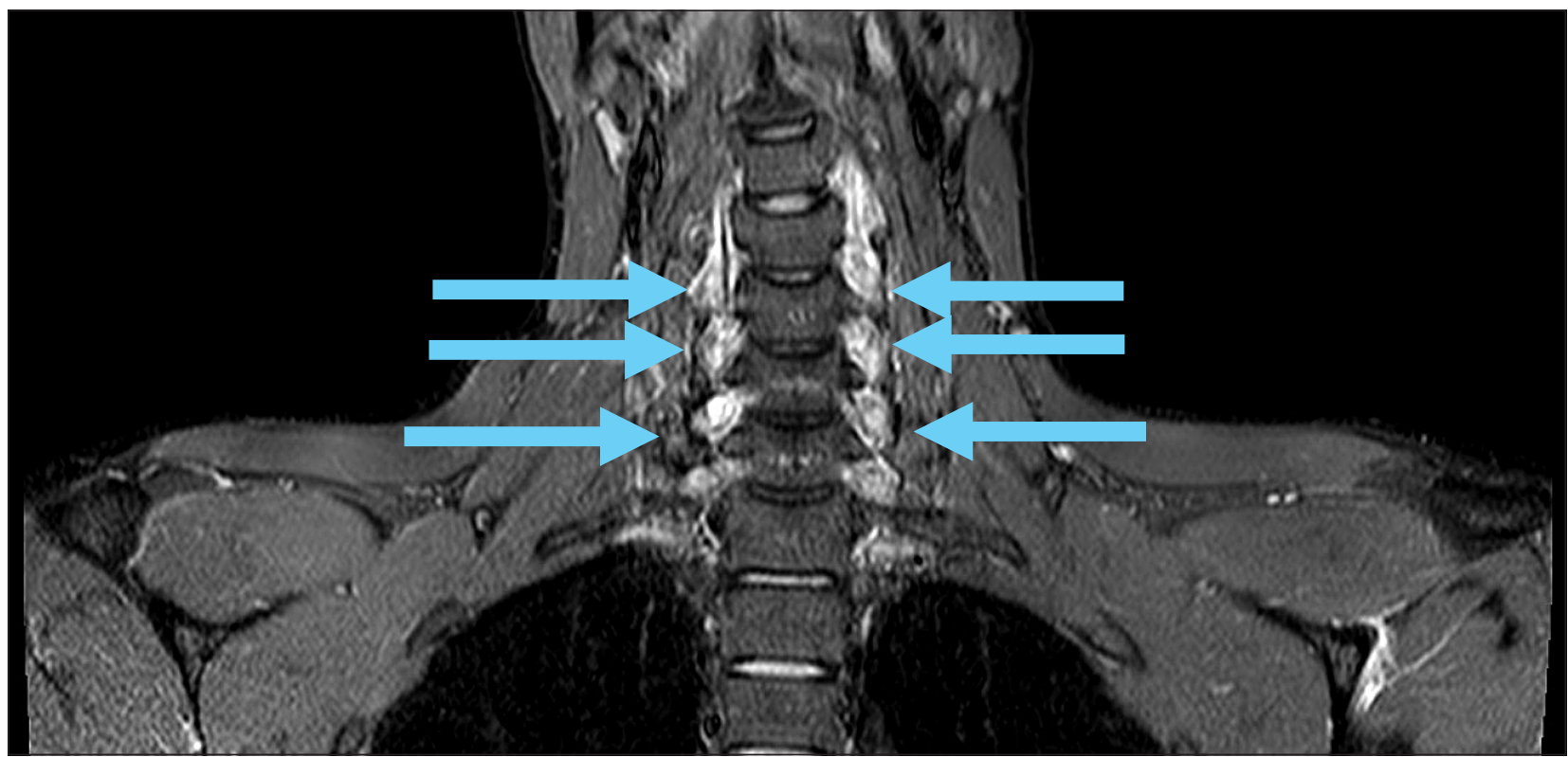

1 pav. Peties rezginio MRT. STIR SHORT TE seka, koronalinis pjūvis.

C4-C8 šaknelių dorzalinių ganglijų ir šaknelių proksimalinių dalių saiki edema - nedideli abipusio brachialinio pleksito požymiai. C5/6 abipus ir C6/7 kairiosios intervertebrinès angos perineuralinès cistos (atsitiktiniai radiniai).

Pacientas aptartas konsiliume, kadangi kliniškai vyravo vangi rankų paraparezė, neišgaunami sausgyslių refleksai rankose, objektyvaus jutimų sutrikimo nestebėta, diferencijuota su daugiažidinine motorine neuropatija su laidumo blokais. Diagnozei patikslinti rekomenduoti papildomi tyrimai. Struktūriniams pakitimams atmesti atliktoje galvos MRT smegenų pusrutuliuose, smegenèlèse, kamiene darinių, patologinio signalo zonų ar kontrastinès medžiagos kaupimo nebuvo matoma. Serume antikūnų prieš $B$. burgdorferi, erkinio encefalito virusą (nors pacientas teigè, kad skiepijosi nuo erkinio encefalito), antikūnų prieš dvispiralę DNR, prieš branduolio antige- nus (ANA), prieš neutrofilų citoplazmą (ANCA) nenustatyta.

Kadangi pacientui poūmiai išsivystè abipuse rankų gili paraparezé, esant atmestiems infekciniams susirgimams (normalūs smegenų skysčio tyrimas ir antikūnų tyrimai) ir kakliniam nugaros smegenų pažeidimui, nuspręsta, kad daugiausia duomenų yra už imuninę uždegiminę abipusio peties rezginio pažeidimo etiologiją, todèl paskirtas gydymas gliukokortikoidais. Trečią hospitalizacijos dieną pacientui paskirtas gydymas prednizolonu $1 \mathrm{mg} / \mathrm{kg}$ (suminė dozè - 70 mg per parą). Teigiamas klinikinis efektas gautas trečią gliukokortikoidų vartojimo parą: žastų jèga pagerèjo

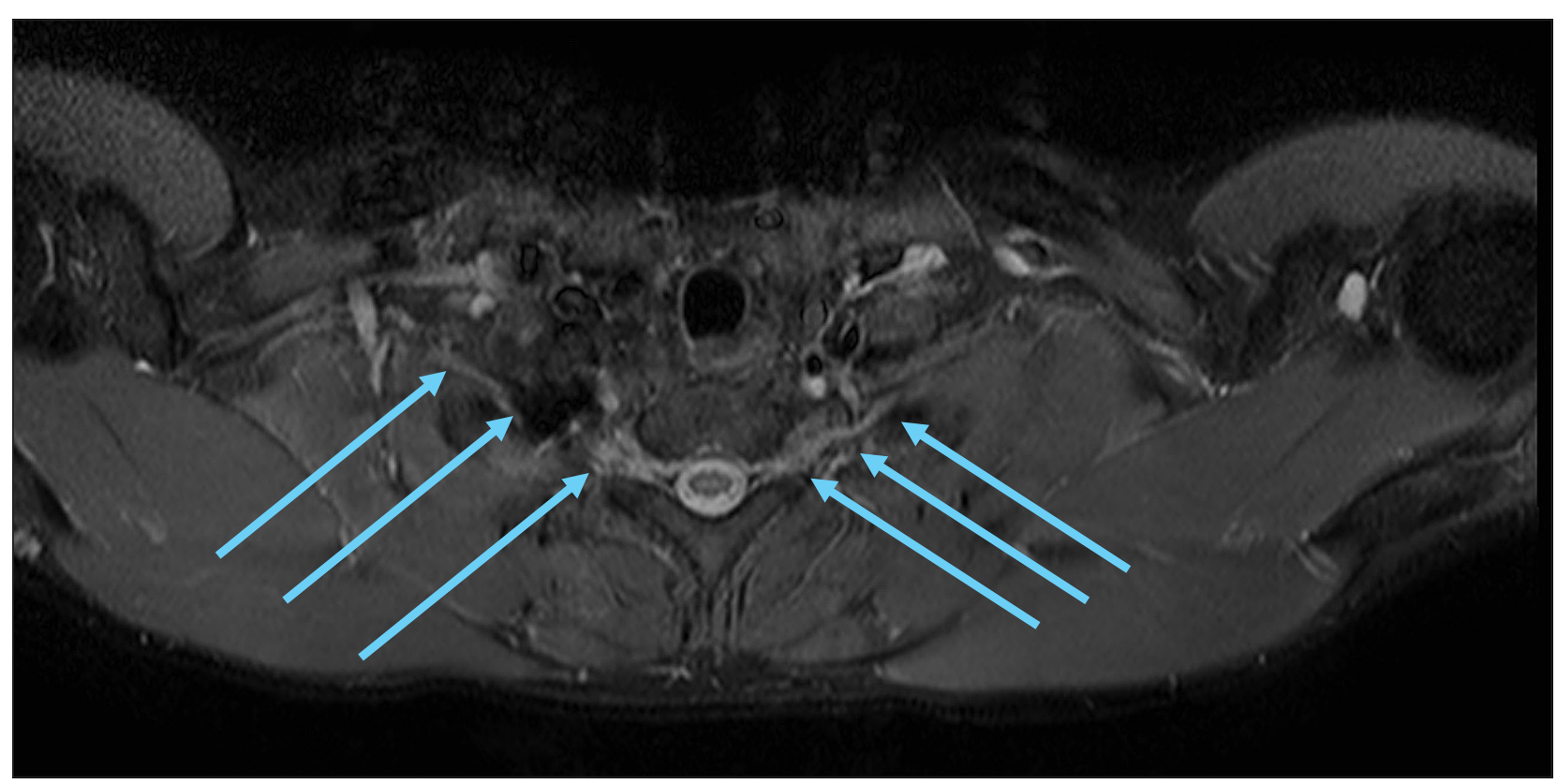

2 pav. Peties rezginio MRT. STIR SHORT TE seka, aksialinis pjūvis.

Peties rezginių proksimalinių dalių saiki edema - saikūs abipusio brachialinio pleksito požymiai. 
iki 3 balų, pamažu pradejo gerèti dilbių judesiai (apie 2 balus), atsirado dvigalvio raumens sausgyslès refleksai. Pacientas nurodè, kad kartais jaučia raumenų trūkčiojimus žastuose.

Praejus savaitei po pirmo elektroneurografijos (ENG) tyrimo, jis pakartotas dinamikoje (4-ą kortikosteroidų vartojimo parą). ENG tyrimas atliktas išplečiant jo apimtị, motoriniai nervai stimuliuoti keliuose taškuose ir tirti proksimaliai segmentai, ieškant laidumo blokų. Rankų motoriniuose ir sensoriniuose nervuose pakitimų nenustatyta, laidumo blokų negauta, $\mathrm{F}$ bangų latencijos buvo normalios.

Aptarus su gydytojais radiologais, nesant pakitimų atliktuose tyrimuose, nuspręsta atlikti peties rezginio MRT, siekiant ịrodyti peties rezginio pažeidimą paraklinikiniais tyrimais. 12-ą hospitalizacijos parą pacientui atliktas peties rezginio MRT (1 ir 2 pav.), kuriame stebèta C4-C8 šaknelių dorzalinių ganglijų ir šaknelių proksimalinių dalių saiki edema - nedideli abipusio brachialinio pleksito požymiai. Taip pat aprašytos C5/6 abipus ir C6/7 kairiosios intervertebrinės angos perineuralinės cistos (atsitiktiniai radiniai). MRT tyrimo metu nustatytas šaknelių patinimas patvirtino uždegiminę jų pažeidimo etiologiją, o geras atsakas ị gydymą gliukokortikoidais disimuninę uždegimo kilmę. Suformuluota galutinè klinikinè diagnozè - ūmi abipusė brachialinė pleksopatija: vangi rankų parezè. Pagal klinikinius ir paraklinikinius duomenis bei gerèjimą, skiriant gliukokortikoidus, susirgimas priskirtas atipiniam LUDP variantui, Lewis-Sumner sindromui.

Gydant paciento būklè pagerèjo, sustiprèjo rankų raumenų jẻga. Išrašant pacientą ị namus 16-ą hospitalizacijos parą rankų jèga pagerèjo iki 3 balų, pacientas pakėlè rankas į viršų, tačiau nepasipriešino, sustiprejjo plaštakų jèga iki 3 balų. Epizodiškai naktị jautè rankų tirpimą, sustingimą.

Rekomenduotas tolesnis reabilitacinis gydymas ir tęsti gydymą prednizolonu $70 \mathrm{mg}$ per dieną 3 savaites, vaistais skrandžio gleivinès protekcijai ir B grupès vitaminais.

Po 3 savaičių gydymo pacientas konsultuotas VUL SK Konsultacinèje poliklinikoje, paciento būklè buvo gerèjanti, rankų jèga proksimaliai - 5 balai, distaliai fleksija 4 balai, ekstenzija - 5 balai, kojų jèga - 5 balai. Jutimų sutrikimo nenustatyta. Sausgyslių refleksai rankose - žemi, kojų - gyvoki, be asimetrijos. Rekomenduota mažinti prednizolono dozę kas 1 savaitę po $5 \mathrm{mg}$, neurologo konsultacija - po 2 mėnesių. Kol kas duomenų apie paciento tolesnę ligos eigą nèra.

\section{APTARIMAS}

Lewis-Sumner sindromas arba MADSAM (angl. multifocal acquired demyelinating sensory and motor neuropathy) - asimetrinis arba daugiažidininis LUDP variantas, kai pažeidžiamos viršutinės ir (ar) apatinès galūnès [3, $6,7]$.

\section{Klinikinis pasireiškimas}

Lewis-Sumner sindromas - tai daugiažidininè igyta demielinizuojanti sensorinè ir motorinė neuropatija, kurios dažniausios klinikinės išraiškos yra jutimų sutrikimas ir jègos sumažėjimas. Kaip jau minėta, pirmajame šios ligos aprašyme minimas tik rankų pažeidimas, vėlesnèse apžvalgose nurodoma, kad gerokai rečiau L-SS gali pasireikšti kojų pažeidimu. L-SS, kai pažeidžiamos tik rankos, plačiai apžvelgtas Y. A. Rajabally ir bendraautorių 2008 m. apžvalgoje. Joje pateikiami 8 L-SS sindromo su viršutinių galūnių pažeidimu atvejų aprašymai ir apžvelgtos 25 studijos, publikuotos iki 2008 m. (82 anksčiau literatūroje aprašyti atvejai) [7]. Vidutinis ligos pasireiškimo amžius buvo 43,1 metų (nuo 9 iki 74 m.), vidutinė ligos trukmė - 5,1 m. Kaip ir daugumoje ankstesnių studijų, išskyrus pirmaji šio sindromo aprašymą, L-SS su viršutinių galūnių pažeidimu dažniau pasireiškė vyrams (vyrų ir moterų santykis - 1,87:1) [7, 11, 12]. L-SS pirmiausia pasireiškè sensoriniais $32,1 \%$ (25 iš 78 ), rečiau - motoriniais 17,9 \% (14 iš 78), o 50 \% atvejų (39 iš 78) - sensomotoriniais simptomais. Pradžioje ryškiai vyravo distalinis ranku pažeidimas, dažniausiai buvo pažeidžiami alkūninis nervas (lot. n. ulnaris) $(75,6 \%, 34$ iš 45$)$ ir vidurinis nervas (lot. n. medianus) $(60 \%, 27$ iš 45), kiek rečiau - stipininis nervas (lot. $n$. radialis) $(31,1 \%, 14$ iš 45$)$. Raumeninis odos nervas (lot. n. musculocutaneus) $(8,9 \%, 4$ iš 45$)$ ir pažastinis nervas (lot. $n$. axillaris) $(13,3 \%, 6$ iš 45$)$ buvo pažeidžiami retai. Galvinių nervu pažeidimas pasitaikė $17,3 \%$ (13 iš 75) pacientų, beveik $50 \%$ atvejų tai buvo optinis nervas [7]. K. Viala ir bendraautorių $2004 \mathrm{~m}$. publikuotoje studijoje aprašyta daugiausia L-SS pacientų iš Y. A. Rajabally bei kolegų nagrinètų studijų. Joje pateikta 16 L-SS sindromo atvejų su vyraujančiu viršutinių galūnių pažeidimu, tai sudare $70 \%$ (16 iš 23 ) visu toje studijoje nagrinètų L-SS pacientų. Joje dažniau, nei platesnèje Y. A. Rajabally studijoje, L-SS pasireiškè sensomotoriniais simptomais - $65 \%$ atvejų (15 iš 23), taip pat buvo dažniau pažeidžiami kiti galviniai nervai: akies judinamasis (lot. n. oculomotorius), skridininis (lot. n. trochlearis), trišakis (lot. n. trigeminus) ir veidinis (lot. n. facialis) [10]. Y. A. Rajabally studijoje skausmas, kaip vyraujantis simptomas, esant ranku pažeidimui, buvo nurodomas $21,7 \%$ atvejų (18 iš 83), nors pirmajame L-SS aprašyme jis buvo minimas kaip vienas iš esminių simptomų $[7,11]$. Sausgyslių refleksai dažniausiai žemesni ar sunkiai išgaunami, o progresuojant ir vèlyvose ligos stadijose refleksai išnyksta [13]. Ligos išplitimo dažnis ị apatines galūnes varijuoja skirtingose studijose, Y. A. Rajabally studijoje $38 \%$ (27 iš 71) atvejų galiausiai pasireiškè ir kojų simptomai, o M. M. Dimachkie ir bendraautoriai nurodo išplitimą ị kojas iki $50 \%$ atvejų $[7,13]$. Lyginant su kitomis L-SS formomis, patikimai dažniau L-SS su viršutinių galūnių pažeidimu neplinta ị kojas $[7,10,13]$.

Šiame straipsnyje pristatomo atvejo klinikinè išraiška yra būdinga L-SS: atvykus buvo išgaunami labai žemi m. triceps sausgyslių refleksai, kitų refleksų rankose neišgauta, todèl galimai ryškesnis buvo alkūninio ir vidurinio 
nervų pažeidimas. Pacientui pasireiškė rankų paraparezė, vyraujant distaliniam viršutinių galūnių pažeidimui, nebuvo kojų jègos sumažejimo. Galimai tai lokalizuota L-SS forma, todèl turi būti atskiriama nuo kitų asimetrinių LUDP variantų [7, 10, 13]. Taip pat pacientas skundèsi alkūnių ir dilbių skausmais, tačiau objektyvaus jutimų sutrikimo tuo metu nestebėta. Kaip jau minèta klinikinių simptomų apžvalgoje, pažeidimas dažnai yra mišrus (ir sensorinis, ir motorinis), tačiau liga tik $50 \%$ atvejų prasideda kartu ir sensoriniais, ir motoriniais simptomais [7]. Galimai hospitalizacijos metu vyravo motoriniai simptomai, objektyvaus jutimų sutrikimo nenustatyta. Kadangi sensorinių simptomų buvimas padeda atskirti L-SS nuo MMN, siekdami išvengti įtraukti ì analizę ne L-SS pacientus, Y. A. Rajabally ir bendraautoriai savo pateikiamoje apžvalgoje L-SS atvejų aprašymų atranką atliko pagal esamus sensorinius simptomus. Buvo reikalingi bent du iš trijų kriterijų: jutiminiai simptomai, objektyvus jutimų sutrikimas ar elektrofiziologiškai patvirtintas jutiminių nervų pažeidimas [7]. Remiantis šiais kriterijais, nagrinejjamas klinikinis atvejis jų neatitiko, tačiau MRT tyrimo metu nustatyti uždegiminiai pakitimai užpakaliniame mazge patvirtino sensorinių nervų pažeidimą. Elektroneurografinio tyrimo metu esant neilgai sirgimo trukmei, jutiminių nervų pažeidimas, kuris prasideda patologiniu procesu užpakaliniuose mazguose (gangliopatija ar kitaip neuropatija), neįrodomas, nes juntamųjų nervų atsakų amplitudès sumažèja tik vystantis nervo aksoninei degeneracijai, šiam procesui reikia laiko [5-7, 15, 16].

Šiuo klinikiniu atveju, pacientas išsakè simptomus, kurie galètų būti priskirti autonominès nervų sistemos pažeidimui - tai prakaitavimas ir tachikardijos epizodai. Autonominès nervų sistemos pažeidimas galimas sergant ūmine uždegimine demielinizuojančia polineuropatija, tačiau duomenų apie jos pažaidą, sergant L-SS, literatūroje nepavyko aptikti [3-14, 18]. Galimai šie simptomai neaprašyti, nes sindromas yra retas, apžvalgų autoriai analizavo nedidelị kiekị pacientų, studijos dažniausiai buvo retrospektyvinès, vidutinè ligos trukmė gerokai ilgesnè, nei šio klinikinio atvejo. Taigi, neaišku, ar mūsų pacientui minèti simptomai atsirado dẻl autonominės nervų sistemos pažeidimo dèl L-SS, ar tai buvo atsitiktiniai, su liga nesusiję nusiskundimai.

\section{Elektrodiagnostiniai tyrimai}

Daugiausia L-SS atvejų su viršutinių galūnių pažeidimu apžvelgiančioje Y. A. Rajabally ir bendraautorių studijoje rankų motorinių nervų laidumo blokai bent viename iš jų nustatomi apie 90 \% (60 iš 67) atvejų, rečiau - kiti demielinizaciją rodantys motorinių nervų pakitimai. Motorinių nervų laidumo blokai - tai pagrindinis elektrodiagnostiniu tyrimų radinys, esant L-SS, lyginant su kitais demielinizaciją rodančiais pakitimais $(p<0,001)$ [7]. Dažniau laidumo blokai aptinkami proksimalinėse nervų dalyse nei distalinėse, todèl reikalinga techniškai teisingai atlikti tyrimą: reikalinga maksimali stimuliacija Erbo taške [7, 10]. Kiti demielinizaciją rodantys pakitimai: distalinio latentinio periodo prailgejjimas, motorinių nervų laidumo greičio sulètèjimas, F bangų latencijos prailgèjimas ar jos nebuvimas, nustatomi apie $50 \%$ atvejų $[7,10]$. Sensorinių nervų veikimo potencialų amplitudès Y. A. Rajabally studijoje buvo sumažejusios arba jie negauti viename ar daugiau sensorinių rankų nervų 83,6 \% (46 iš 55) atvejų, taip pat ir daugumoje K. Viala studijos pacientų [7, 10]. Vis daugèja studijų, kad, diagnozuojant LUDP ir jos retesnius variantus, kai nerandama pakitimų atliekant elektroneurografiją, galima atlikti somatosensorinių sukeltujų potencialų tyrimą $[15,16]$. Tai padètų gavus normalius sensorinių nervų elektrodiagnostinio tyrimo rezultatus, esant proksimaliniams sensoriniams laidumo blokams $[15,16]$. Kojų motorinių nervų laidumo blokai, kai L-SS pasireiškia rankų pažeidimu, buvo randami retai - mažiau nei trečdaliu atvejų (28,3\%, 12 iš 46), o sensorinių kojų nervų pakitimai $34,4 \%$ (11 iš 32) atvejų [7]. Retrospektyvinèse studijose pabrèžiama, kad nemažai atvejų aprašymų pateikiama tik dalis elektrofiziologinių tyrimų rezultatų ir dažnai randami pakitimai neatitinka demielinizacijai patvirtinti reikalingų kriterijų, remiantis galiojančiais kriterijais [7, 10, 17]. Šis klinikinis atvejis taip pat neatitiko šių kriterijų. Tai galime paaiškinti neilga sirgimo trukme ir MRT įrodytais pakitimais proksimalinėse nervų dalyse - šaknelèse ir užpakaliniuose mazguose.

\section{Laboratoriniai tyrimai}

D. S. Saperstein ir bendraautoriu $1999 \mathrm{~m}$. studijoje buvo nustatyta, kad pacientams, sergantiems L-SS, padidejjęs baltymo kiekis smegenų skystyje aptinkamas iki $82 \%$ atvejų [18]. Vèlesnèse studijose baltymo kiekio padidèjimas smegenų skystyje L-SS sergantiems pacientams nurodomas apie $40 \%$ atvejų ir dažniausiai yra vidutinis [10]. Lyginant su kitais L-SS variantais, L-SS formai su vyraujančiu rankų pažeidimu rečiau randamas padidejęs baltymo kiekis smegenų skystyje, nei kitais atvejais [7]. Aptariamo paciento atveju pakitimų smegenų skystyje nebuvo.

Vienas iš laboratorinių tyrimų, padedantis atskirti MMN ir L-SS neuropatijas, yra antikūnų prieš monosialotetraheksozilgangliozidus (GM1) (anti-GM1) tyrimas, šie antikūnai nebūdingi L-SS [7, 10, 19]. Anti-GM1 antikūnai A. Pestronk ir kolegu $1988 \mathrm{~m}$. buvo susieti su tais pačiais metais aprašytais grynos motorinès neuropatijos su laidumo blokais (MMN) klinikiniais atvejais [19]. Y. A. Rajabally ir bendraautorių analizejje pateikiama, kad pacientams su L-SS retai galima aptikti nedaug padidejusi antiGM1 antikūnų titrą ( $<5 \%$ atvejų), tačiau labai didelių titrų $(\geq 1: 6400)$ nebuvo rasta [7].

\section{Radiologiniai tyrimai}

MRT tyrimas vis dažniau naudojamas, tiriant pacientus, kuriems ịtariama imuninė neuropatija, ir yra vienas iš papildomų kriterijų, diagnozuojant LUDP $[17,20]$. Y. A. Rajabally ir bendraautorių 2014 metų publikacijoje aptariami 5 atvejai, kai MRT padejo nustatyti ar patvirtino L-SS diagnozę ir pagreitino imunoterapijos pradejjimą. Reko- 
menduojama MRT atlikta su T2 STIR (angl. Short Tau Inversion recovery) seka be kontrasto, joje buvo stebimas hiperintensyvus signalas nervinių šaknelių ir (ar) peties rezginio srityje [20]. Šių pokyčių radimas pagreitino pradèti imunomoduliuojanti gydymą, kai, kaip ir mūsų straipsnyje pateiktame klinikiniame atvejyje, kituose tyrimuose (pvz., elektroneuromiografijoje) pakitimų nerandama arba jie yra nežymūs. B. A. Jonbloed ir bendraautorių $2016 \mathrm{~m}$. publikuotame tyrime lyginti pacientų, kuriems diagnozuota MMN, L-SS ar LUDP, MRT tyrimai. Asimetrinis pažeidimas buvo patikimai būdingesnis MMN ir L-SS nei LUDP, tačiau nebuvo rasta ryšio tarp pakitimų peties rezginio MRT tyrime ir specifinès klinikinès išraiškos, ligos prognozės ir atsako ị gydymą, todèl kol kas, autorių nuomone, tikslingi tolesni tyrimai, įvertinant MRT tyrimo reikšmę imuninių neuropatijų diagnostikai [21].

\section{Patologiniai radiniai}

Kaip ir LUDP atveju, nervo biopsijos tikslingumas yra diskusijų objektas. Ji atliekama tada, kai kituose tyrimuose (ypač elektrodiagnostiniuose) pakitimų nerandama [22]. Atliekant sensorinio odos nervo biopsiją, randama pakitimų, panašių i cacientų, sergančių LUDP. Aprašomi demielinizacijai būdingi pakitimai: suplonèjęs mielino sluoksnis, išsisklaidžiusios demielinizuotos skaidulos, „Svogūno galvą“" (angl. „onion bulb ") primenantys pakitimai, skaidulų asimetrinè demielinizacija ar remielinizacija pluošteliuose [11, 13, 22]. Aptariamo paciento atveju nervo biopsija ịprastinėje vietoje greičiausiai būtų neinformatyvi dẻl neilgos ligos trukmės ir proksimalinio pažeidimo distalinejje nervo dalyje pakitimų nenustatytume.

\section{Gydymas}

Prieš skiriant gydymą, labai svarbu ịsitikinti, kad diagnozė yra teisinga, atskiriant L-SS nuo MMN, nes L-SS atsako ic gydymą gliukokortikoidais, o MMN steroidai neefektyvūs arba gali pabloginti ligos eigą $[3,7,13]$. Daugumoje studijų pabrèžiama, kad suformuluoti gydymo rekomendacijas LUDP, ypač jos atipiniams variantams, yra labai sunku dèl nagrinejjamų atvejų nedetalaus aprašymo, neaiškios gydymo trukmès ar dozių ir nepateiktų atsako ị gydymą kriterijų [7, 13, 17]. 2010 m. EFNS/PNS (angl. European Federation of Neurological Societies/Peripheral Nerve Society) pateikiamos atnaujintos LUDP gydymo rekomendacijos, kuriose sensorinei ir motorinei LUDP gydyti rekomenduojami intraveniniai imunoglobulinai (IVIg) (A lygio rekomendacija) ar gliukokortikoidai (C lygio rekomendacija). Jei LUDP grynai motorine - IVIg yra pirmo pasirinkimo gydymo metodas (GPR - geros praktikos rekomendacija, angl. Good Practice Point, GPP). Esant neefektyviam gydymui IVIg ir gliukokortikoidais, rekomenduojama taikyti gydymą gydomosiomis aferezėmis (A lygio rekomendacija) [17]. Y. A. Rajabally ir bendraautorių 2009 metų apžvalgoje, kurioje nagrinėti L-SS atvejai su vyraujančiu viršutinių galūnių pažeidimu, pateikiama, kad per 80 \% gydytų pacientų atsako ị gydymą intraveniniais imunoglobuli- nais, kurie galimai efektyvesni nei gliukokortikoidai, tačiau patikimo skirtumo negauta $(p=0,075) .7,4 \%$ (2 iš 27) steroidus vartojusių pacientų būklè pablogèjo, vartojusių IVIg pablogèjimo nestebèta. İvertinti gydymo efektyvumą taip pat apsunkinta tai, kad ligos prognozè yra palanki apie $40 \%$ pacientų, kurie galiausiai stabilizuojasi be gydymo [7]. K. Viala studijoje pacientams su L-SS gydymas IVIg buvo efektyvus pusei pacientų, o gliukokortikoidais - trečdaliui [10].

Pagal EFNS/PNS 2010 metų rekomendacijas, IVIg turètų būti skiriamas esant vidutinio sunkumo ar sunkiam ligos pasireiškimui. Pradinè dozè - 2,0 g/kg, padalinant dozę per 2-5 dienas. Pagerẻjimas trunka 2-6 savaites, todèl pakartotinès dozès turi būti vartojamos sprendžiant individualiai. Aiškių gliukokortikoidų skyrimo rekomendacijų nėra, dažniausiai skiriama $60 \mathrm{mg}$ per dieną (arba $1 \mathrm{mg} / \mathrm{kg}$ per parą), dozé palaikoma, o vẻliau lètai mažinama. Dozės mažinimas gali trukti ilgai - vienerius ar kelerius metus. Gydomųjų aferezių vartojimą riboja nepageidaujamos reakcijos, tačiau jos priskiriamos pirmos eilès gydymui. Jeigu pirmos eilès gydymas neefektyvus ar palaikomosios dozès sukelia nepageidaujamų reiškinių, rekomenduojama pereiti prie kito pirmos eilès gydymo ir tik vèliau taikyti kelis gydymo būdus kartu ar pridèti imunosupresantą. Dèl imunosupresantų skyrimo rekomendacijų reikalingi tolesni tyrimai [17]. K. Viala ir kolegų pateikta rekomendacija pirmiausia gydyti IVIg $2 \mathrm{~g} / \mathrm{kg}$ kursu. Jei nèra atsako į gydymą po 2-3 gydymo kursų, reikètų skirti prednizoloną $1 \mathrm{mg} / \mathrm{kg}$ per dieną 4-6 savaites, vèliau pamažu mažinant [10]. Labai sunku vertinti ilgalaiki gydymo efektą dèl mažo tiriamujų skaičiaus studijose. S. Attarian ir bendraautorių 2010 metų tyrime buvo vertintas ilgalaikis gydymo efektyvumas 15 L-SS pacientų. Visiems pacientams, kaip pirmo pasirinkimo gydymas, buvo skirti IVIg kursai. Po vienerių metų stebejimo $46,7 \%$ (7 iš 15 ) gydymas buvo efektyvus, 40 \% (6 iš 15) būklè buvo stabili, 13,3 \% (2 iš 15) būklè pablogejo. Po penkerių metų iš 10 stebimų pacientų $50 \%$ (5 iš 10) būklè pagerẻjo, $40 \%$ liko stabili, vieno paciento būklè pablogèjo. Pacientams, kuriems kartu su IVIg buvo skirta gliukokortikoidų, 50 \% (2/4) atvejų pasireiškė pablogejimas [23]. Aptariamo klinikinio atvejo atsakas ị gydymą gliukokortikoidais buvo labai geras, jau trečią steroidų skyrimo parą gautas teigiamas klinikinis efektas ir paciento būkle dinamikoje gerèjo. Jei nebūtų pagerẻjimo, taikant ši gydymą, pacientui skirtume IVIg, tačiau tam reikalingas Ligonių kasų leidimas. Antra vertus, nors gydymas IVIg dažniau būna efektyvus, tačiau, jei būna atsakas ị gydymą gliukokortikoidais, jis tęsiasi ilgiau [24].

\section{APIBENDRINIMAS}

Pateikiamas klinikinis atvejis patvirtina, kad imuniniu neuropatijų diagnostika yra sudètinga dèl panašios klinikinės išraiškos, gali nebūti pakitimų ịprastiniuose elektrodiagnostiniuose, laboratoriniuose tyrimuose. Reikia kompleksiškai vertinti visus šiuos duomenis, atlikti rečiau 
diagnostikai naudojamus tyrimus (pvz., peties rezginio MRT) ir stebèti pacientą, nustatant tikslią diagnozę bei pasirenkant tinkamiausią gydymą.

\section{Literatūra}

1. Ferrante MA. Brachial plexopathies. Continuum (Minneap Minn) 2014; 20(5): 1323-42. https://doi.org/10.1007/ 978-1-4614-6567-6_46

2. Bromberg MB. Brachial plexus syndromes. UpToDate. Waltham, MA: UpToDate Inc. http://www.uptodate.com (Accessed on December 15, 2017).

3. Eldar AH, Chapman J. Guillain Barré syndrome and other immune mediated neuropathies: diagnosis and classification. Autoimmun Rev 2014; 13(4-5): 525-30. https://doi.org/ 10.1016/j.autrev.2014.01.033

4. Lange D, Robinson-Papp J. Immune-mediated neuropathies. Shefner JM, Dashe JF, eds. UpToDate. Waltham, MA: UpToDate Inc. http://www.uptodate.com (Accessed on December 20, 2017).

5. Dalakasab MC. Pathogenesis of immune-mediated neuropathies. Biochim Biophys Acta 2015; 1852(4): 658-66. https://doi.org/10.1016/j.bbadis.2014.06.013

6. Mathey EK, Park SB, Hughes RAC, Pollard JD, Armati PJ, Barnett $\mathrm{MH}$, et al. Chronic inflammatory demyelinating polyradiculoneuropathy: from pathology to phenotype. J Neurol Neurosurg Psychiatry 2015; 86: 973-85. https://doi.org/10.1136/jnnp-2014-309697

7. Rajabally YA, Chavada G. Lewis-sumner syndrome of pure upper-limb onset: diagnostic, prognostic, and therapeutic features. Muscle Nerve 2009; 39(2): 206-20. https://doi.org/ 10.1002/mus.21199

8. Lewis RA. Chronic inflammatory demyelinating polyneuropathy: Etiology, clinical features, and diagnosis. Shefner JM, Dashe JF, eds. UpToDate. Waltham, MA: UpToDate Inc. http://www.uptodate.com (Accessed on December 18, 2017).

9. Viala K, Maisonobe T, Stojkovic T, Koutlidis R, Ayrignac X, Musset $\mathrm{L}$, et al. A current view of the diagnosis, clinical variants, response to treatment and prognosis of chronic inflammatory demyelinating polyradiculoneuropathy. J Peripher Nerv Syst 2010; 15(1): 50-6. https://doi.org/10.1111/ j.1529-8027.2010.00251.x

10. Viala K, Renie L, Maisonobe T, Behin A, Neil J, Leger JM, et al. Follow-up study and response to treatment in 23 patients with Lewis-Sumner syndrome. Brain 2004; 127(9): 2010-17. https://doi.org/10.1093/brain/awh222

11. Lewis RA, Sumner AJ, Brown MJ, Asbury AK. Multifocal demyelinating neuropathy with persistent conduction block. Neurology 1982; 32: 958-64. https://doi.org/10.1212/ WNL.32.9.958

12. Oh SJ, Claussen GC, Dae SK. Motor and sensory demyelinating mononeuropathy multiplex (multifocal motor and sensory demyelinating neuropathy): a separate variant of chronic inflammatory demyelinating polyneuropathy. J Periph Nerv Syst 1997; 2: 362-9.

13. Dimachkie MM, Barohn RJ, Katz J. Multifocal motor neuropathy, multifocal acquired demyelinating sensory and motor neuropathy and other chronic acquired demyelinating polyneuropathy variants. Neurologic Clinics 2013; 31(2): 533-55. https://doi.org/10.1016/j.ncl.2013.01.001

14. Vallat JM. Chronic inflammatory demyelinating polyneuropathy. Orphanet; December 2010; http://www.orpha.net (Accessed on January 3, 2018).
15. Devic P, Petiot P, Mauguiere F. Diagnostic utility of somatosensory evoked potentials in chronic polyradiculopathy without electrodiagnostic signs of peripheral demyelination. Muscle Nerve 2016; 53: 78-83. https://doi.org/10.1002/ mus. 24693

16. Clerici AM, Nobile-Orazio E, Mauri M, Squellati FS, Bono GG. Utility of somatosensory evoked potentials in the assessment of response to IVIG in a long-lasting case of chronic immune sensory polyradiculopathy. BMC Neurology 2017; 17: 127. https://doi.org/10.1186/ s12883-017-0906-2

17. Van den Bergh PY, Hadden RD, Bouche P, Cornblath DR, Hahn A, Illa I, et al. European Federation of Neurological Societies/Peripheral Nerve Society Guideline on management of chronic inflammatory demyelinating polyra diculoneuropathy: report of a joint task force of the European Federation of Neurological Societies and the Peripheral Nerve Society-First Revision. J Peripher Nerv Syst 2010; 15(1): 1-9. https://doi.org/10.1111/j.1529-8027.2010.00245.x

18. Saperstein DS, Amato AA, Wolfe GI, Katz JS, Nations SP, Jackson CE, et al. Multifocal acquired demyelinating sensory and motor neuropathy: the Lewis-Sumner syndrome. Muscle Nerve 1999; 22: 560-6. https://doi.org/10.1002/ (SICI) 1097-4598(199905)22:5<560::AID-MUS2>3.0.CO; 2-Q

19. Pestronk A, Cornblath DR, Ilyas AA, Baba H, Quarles RH, Griffin JW, et al. A treatable multifocal motor neuropathy with antibodies to GM1 ganglioside. Ann Neurol 1988; 24: 73-8. https://doi.org/10.1002/ana.410240113

20. Rajabally YA, Knopp MJ, Martin-Lamb D, Morlese J. Diagnostic value of MR imaging in the Lewis-Sumner syndrome: a case series. J Neurol Sci 2014; 342(1-2): 182-5. https://doi.org/10.1016/j.jns.2014.04.033

21. Jongbloed BA, Bos JW, Rutgers D, van der Pol WL, van den Berg LH. Brachial plexus magnetic resonance imaging differentiates between inflammatory neuropathies and does not predict disease course. Brain and Behavior 2017; 7(5): 632-7. https://doi.org/10.1002/brb3.632

22. Vallat JM, Tabaraud F, Magy L, Torny F, Bernet-Bernady P, Macian F, et al. Diagnostic value of nerve biopsy for atypical chronic inflammatory demyelinating polyneuropathy: evaluation of eight cases. Muscle Nerve 2003; 27: 478. https://doi.org/10.1002/mus.10348

23. Attarian S, Verschueren A, Franques J, Salort-Campana E, Jouve E, Pouget J. Response to treatment in patients with Lewis-Sumner syndrome. Muscle Nerve 2011; 44: 179-84. https://doi.org/10.1002/mus.22024

24. Nobile-Orazio E, Gallia F, Terenghi F, Bianco M. Comparing treatment options for chronic inflammatory neuropathies and choosing the right treatment plan. Expert Review of Neurotherapeutics 2017; 17(8): 755-65. https://doi.org/ $10.1080 / 14737175.2017 .1340832$

\section{Regelskytė, A. Klimašauskienė, G. Kaubrys}

\section{LEWIS-SUMNER SYNDROME: SUBACUTE BILATERAL LESION OF BRACHIAL PLEXUS}

\section{Summary}

Lewis-Sumner syndrome (LSS) is a multifocal acquired demyelinating sensory and motor neuropathy considered as an asymmetric variant of chronic inflammatory demyelinating polyneuropathy affecting the upper and/or lower extremities. 
The most common clinical presentations of Lewis-Sumner syndrome are asymmetrical or multifocal sensory disturbances and weakness, electrophysiologically characterized by the presence of motor conduction blocks. In the case report, L-SS affected only the upper limbs, laboratory and electrophysiological testing was normal. Lewis-Sumner syndrome was diagnosed after brachial plexus magnetic resonance imaging. Since Lewis-Sumner syndrome is a rare disor- der, its diagnosis and treatment are complicated as studies with a small number of patients and the results are often controversial.

Keywords: Lewis-Sumner syndrome, multifocal acquired demyelinating sensory and motor neuropathy, MADSAM.

Gauta:

Priimta spaudai:

20180102

20180126 